\title{
ELECTRONIC CUSTOMER RELATIONSHIP MANAGEMENT SEBAGAI PENUNJANG PELAYANAN PELANGGAN DI PT. BINTANG JASA GEMILANG
}

\author{
Meta Amalya Dewi ${ }^{1}$ \\ Anggi Anggriani ${ }^{2}$ \\ Jaka Mahmud $^{3}$
}

Email : meta@raharja.info, anggi.anggriani@raharja.info,jaka.mahmud@raharja.info

\begin{abstract}
ABSTRAK
Pesatnya pertumbuhan ekonomi dan pembangunan di berbagai bidang, mendorong terpenuhinya kebutuhan perpindahan barang dari satu tempat ke tempat lain. PT. Bintang Jasa Gemilang merupakan PT. Bintang Jasa Gemilang merupakan perusahaan yang bergerak dibidang jasa pengiriman barang yang sedang berkembang di Indonesia, melayani pengiriman barang melalui jalur darat, laut maupun udara yang dapat menjangkau berbagai kepulauan di Indonesia. Kompetisi yang ketat diantara perusahaan logistik menjadikan kepuasan pelanggan sebagai parameter perusahaan dapat terus bertahan dan berkembang. Dalam rangka menjaga dan mempertahankan loyalitas pelanggan dibutuhkan customer relationship management dengan memanfaatkan perkembangan komputer dan IT yang selanjutnya disebut electronic customer relationship management (e-CRM) sebagai upaya meningkatkan pelayanan terbaik kepada pelanggan. Faktanya pengelolaan hubungan pelanggan yang berjalan pada perusahaan masih jauh dari ideal, pelanggan masih sulit mengetahui informasi status pengiriman barang demikian halnya proses order dilakukan melalui fax dan email yang harus diinput ulang dalam pengolahan dan penyimpanan data oleh admin pengiriman dengan menggunakan microsoft excel, yang berakibat keterlambatan dalam pembuatan laporan pengiriman barang. Penelitian ini dibuat menggunakan metode desain eksploratori melalui tahap analisa dengan alat bantu SWOT dan pengembangan sistem berorientasi objek dengan software PHP, MySQL, Xampp dan Macromedia Dreamweaver CS5. Hasil akhir penelitian ini berupa aplikasi e-CRM yang dapat digunakan sebagai penunjang dalam meningkatkan pelayanan kepada pelanggan sebagai upaya mempertahankan loyalitas mereka kepada perusahaan.
\end{abstract}

Kata kunci: Pelayanan, hubungan baik, pelanggan, loyalitas.

\begin{abstract}
The rapid economic growth and development in various fields, encourages fulfillment of movement of goods from one place to another. PT Bintang Jasa Gemilang is a company engaged in the delivery service that is growing in Indonesia, to ship goods by land, sea, or air that reach various islands in Indonesia. Intens competition among logistic companies making customer satisfaction as the company parameter to survive and thrive. Customer relationship management needs by leveraging the development of computers and IT hereinafter called electronic customer relationship management (eCRM) as in an effort to improve service to customers. The fact that the management between the customer and the company is still far from ideal, the customer is still difficult to find shipping status information such as order processing is done by fax and email to be re-inputted in the processing and storage of data by admin shipment by using Microsoft excel, which resulted in the delay of delivery report. This study was made using exploratory design through the analysis stages of SWOT analysis with tools and object-oriented system development with software PHP, MySQL, Xampp and Macromedia Dreamweaver CS5. The final results of this study in the form of e-CRM application which can be used as a support in improving service to customers in order to maintain their loyalty to the company.
\end{abstract}

Key word: Services, good relationship, customer, loyality 


\section{PENDAHULUAN}

Seiring perkembangan teknologi komputer khususnya dibidang informasi yang berkembang pesat, sehingga membuat banyak pelaku bisnis mengikuti arah kemajuan di setiap zaman. Setiap tahunnya pertambahan pelaku bisnis dibidang jasa pengiriman barang di Indonesia semakin meningkat, baik yang bergerak di dalam skala kecil hingga besar, maupun skala domestik hingga internasional. Di Indonesia sendiri jasa pengiriman barang memiliki peran yang cukup penting bagi pendistibusian barang, mengingat Indonesia merupakan negara kepulauan yang terpisah secara geografis oleh banyak lautan sehingga membutuhkan waktu yang cukup panjang dalam pendistibusian barang. PT. Bintang Jasa Gemilang sebagai pelaku bisnis yang tergolong masih muda dalam bidang jasa pengiriman barang perlu memikirkan bagaimana caranya agar pelayanan yang diberikan kepada pelaggan menjadi lebih baik sehingga usaha yang dijalankan tersebut diperolehnya loyalitas pelanggan yang dapat menghasilkan laba yang terus meningkat. Sementara loyalitas pelanggan akan didapatkan ketika pelanggan merasa puas atas pelayanan yang mereka terima. Untuk mewujudkan semua hal itu diperlukan pengelolaan hubungan baik terhadap pelanggan, dimulai dari proses order yang mudah, proses pengambilan barang yang cepat, proses transaksi pembayaran, informasi status pengiriman barang hingga informasi-informasi lain baik yang dibutuhkan pelanggan maupun informasi lainnya dalam rangka menjaga hubungan baik dengan pelanggan.

Faktanya, kondisi yang terjadi di PT. Bintang Jasa Gemilang belum seluruhnya berjalan ideal, dalam menerima order pengiriman masih dilakukan secara tradisional melalui fax atau email yang selanjutnya data tersebut diinput ke dalam aplikasi spread sheet sederhana, hal tersebut dirasakan sangat jauh dari optimal terutama ketika pelanggan meminta informasi status pengiriman barang, admin masih harus mencari melalui data order yang belum terintegrasi antara customer dengan admin pengiriman dan juga menyebabkan keterlambatan dalam pembuatan laporan pengiriman barang.

Berikut di bawah ini merupakan gambaran proses penerimaan order, proses pick up (pengambilan barang), pengiriman barang, konfirmasi status pengiriman, sampai dengan proses pembuatan laporan dengan menggunakan diagram use case yang dapat dilihat di bawah ini :

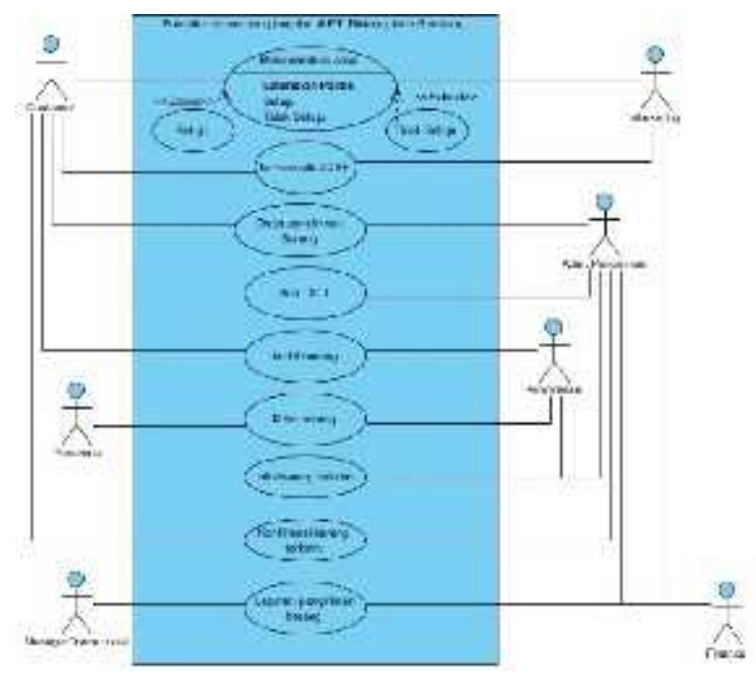

Gambar 1. Usecase Diagram Proses Yang Berjalan.

Pada gambar 1 di atas, perusahaan melalui marketing membuat penawaran jasa kepada calon pelanggan atau memberikan informasi promo produk kepada pelanggan, kemudian admin pengiriman menerima order dan membuat surat tanda terima (STT) selanjutnya bagian pengiriman mengambil barang di tempat customer dan mengirimkannya ke penerima 
lalu membuat laporan barang terkirim kepada admin pengirim yang akan dilanjutkan oleh admin pengirim memberikan konfirmasi barang terkirim kepada customer dan membuat laporan pengiriman barang kepada bagian finance dan kepada manager operational.

\section{TINJAUAN PUSTAKA}

\section{1 e-CRM}

Menurut Turbban [7], "e-CRM adalah CRM yang diterapkan secara electronic dengan menggunakan web browser, internet dan media elektronik lain seperti email, call center, dan personalisasi, eCRM kadang-kadang juga disebut eService"

\section{Tujuan e-CRM}

Menurut Turbban [7] bahwa manfaat utama dari e-CRM adalah penyediaan layanan pelanggan yang unggul melalui penggunaan internet dan teknologi IT. Dengan kata lain, eCRM memberikan keuntungan atau manfaat seperti antara lain :

1. Membuat pelanggan senang dengan menyediakan pilihan produk dan jasa.

2. Putusan dan respon terhadap masalah dengan cepat.

3. Akses ke informasi yang mudah dan cepat, dan lainnya.

\section{Jasa Pengiriman Barang}

Menurut Suyono [8] "Jasa pengiriman barang adalah usaha yang bertujuan untuk memberikan jasa pelayanan atau pengurusan atas seluruh kegiatan yang diperlukan bagi terlaksananya pengiriman, pengangkutan dan penerimaan barang dengan menggunakan multimodal transport baik melalui darat, laut dan atau udara”.

\section{METODE PENELITIAN}

Pada penelitian ini penulis menggunakan metode desain eksploratori melalui tahap analisis sistem dan proses bisnis dilanjut pengembangan sistem. Di tahap analisis, penulis menggunakan tools SWOT Analysis. Di tahap perancangan/ pengembangan penulis menggunakan menggunakan pendekatan prototype dengan alat bantu UML (Unified Modeling Language) yang merupakan suatu kumpulan konvensi pemodelan yang digunakan untuk menentukan atau menggambarkan sebuah sistem software yang terkait dengan objek [3] dengan membuat usecase diagram, activity diagram dan class diagram. Adapun langkahlangkah prototype terdiri dari 4 kegiatan yaitu :

1. Review Sistem dan Data. Pada kegiatan ini dilakukan dengan pendekatan bottom-up analysis, yaitu dengan melakukan pengumpulan dan indentifikasi sumber data, cara pengaksesan data serta kebutuhan data.

2. Rancangan Prototype. Pada kegiatan ini digunakan pendekatan top-down dan bottom-up secara bersama-sama. Prototype digunakan dalam pengembangan perangkat lunak menggunakan PHP, Dreamweaver CS5, MySQL dan Xampp.

3. Perbaikan prototype, setelah desain prototype dirancang selanjutnya direview bersama dengan pengguna untuk melihat sejauh mana kesesuaian antara progress pekerjaan dengan kebutuhan pengguna.

4. Release, pada tahap ini, aplikasi siap diimplementasikan. Selanjutnya senantiasa dievaluasi untuk dilakukan perbaikan berkelanjutan. 
Tahapan pengembangan aplikasi ini dapat dilihat pada gambar 2 berikut di bawah ini.

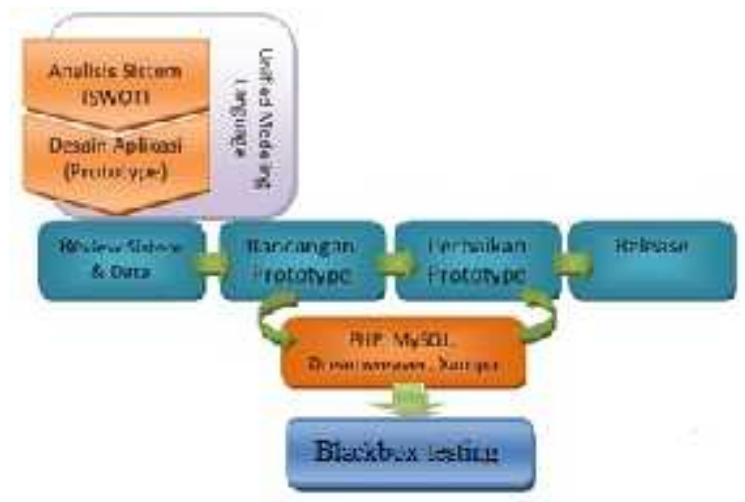

Gambar 2 Tahapan Desain Aplikasi eCRM.

\section{HASIL ANALISA DAN PEMBAHASAN}

\section{Analisis SWOT}

Analisis SWOT digunakan dalam rangka mengindentifikasi berbagai faktor secara sistematis untuk merumuskan suatu strategi. Analisa ini didasarkan pada logika yang dapat memaksimalkan kekuatan (Strength) dan peluang (Opportunity), namun secara bersamaan dapat meminimalkan kelemahan (Weakness) dan ancaman (Threat) [6]. Analisa ini dikategorikan dalam 2 bagian yaitu: internal (kekuatan dan kelemahan) serta eksternal (peluang dan ancaman) perusahaan. Berikut adalah hasil analisa faktor internal dan eksternal perusahaan yang dapat dilihat pada tabel di bawah ini.

Tabel 1. Faktor-Faktor Strategi Internal dan Eksterna

\begin{tabular}{|c|c|}
\hline $\begin{array}{c}\text { Faktor-Faktor } \\
\text { Strategi Internal }\end{array}$ & $\begin{array}{c}\text { Faktor-Faktor } \\
\text { Strategi } \\
\text { Eksternal }\end{array}$ \\
\hline Kekuatan/Strengh & Kelemahan/Wea \\
\hline
\end{tabular}

\begin{tabular}{|c|c|}
\hline $\begin{array}{l}\text { ts } \text { (S) } \\
\text { 1. Tersedianya } \\
\text { sarana } \\
\text { pendukung } \\
\text { teknologi } \\
\text { informasi } \\
\text { seperti akses } \\
\text { internet. } \\
\text { 2. Customer tetap } \\
\text { yang selalu } \\
\text { menggunakan } \\
\text { jasa perusahaan. } \\
\text { 3. SDM yang } \\
\text { berkualifikasi di } \\
\text { bidang } \\
\text { informasi yang } \\
\text { cukup baik. } \\
\text { Peluang/Opportun } \\
\text { ities (O) } \\
\text { 1. Ketersediaan } \\
\text { informasi yang } \\
\text { cukup banyak } \\
\text { dan luas } \\
\text { melalui } \\
\text { internet } \\
\text { 2. Perkembangan } \\
\text { teknologi } \\
\text { informasi yang } \\
\text { terus } \\
\text { meningkat. }\end{array}$ & $\begin{array}{l}\text { knesess }(\mathbf{W}) \\
\text { 1. Belum } \\
\text { tersedianya } \\
\text { aplikasi yang } \\
\text { menyediakan } \\
\text { informasi } \\
\text { yang } \\
\text { dibutuhkan } \\
\text { customer. } \\
\text { 2. Masih adanya } \\
\text { keterlambatan } \\
\text { informasi } \\
\text { status } \\
\text { pengiriman } \\
\text { barang. } \\
\text { 3. Terjadinya } \\
\text { human error. } \\
\text { Ancaman/Threat } \\
\text { s (T) } \\
\text { 1. Keberadaan } \\
\text { pesaing } \\
\text { dibidang } \\
\text { industri yang } \\
\text { sama. } \\
\text { 2. Gangguan } \\
\text { jaringan } \\
\text { internet }\end{array}$ \\
\hline
\end{tabular}

Berdasarkan tabel di atas, maka dilakukan analisa untuk mencari strategi dengan menggunakan kekuatan yang ada untuk memanfaatkan peluang yang tersedia (strategi S-O) serta menggunakan kekuatan yang dimiliki untuk mengatasi ancaman yang ada (strategi S-T). Selain itu dianalisa pula strategi untuk mengurangi kelemahan yang dimiliki dalam meraih peluang yang ada (strategi W-O) maupun mengatasi ancaman yang ada (strategi W-T). Rangkuman hasil analisa strategi tersebut dapat dilihat pada tabel berikut. 
Tabel 2. Rangkuman Strategi $S-O, S-T, W$ $O$, dan $W-T$

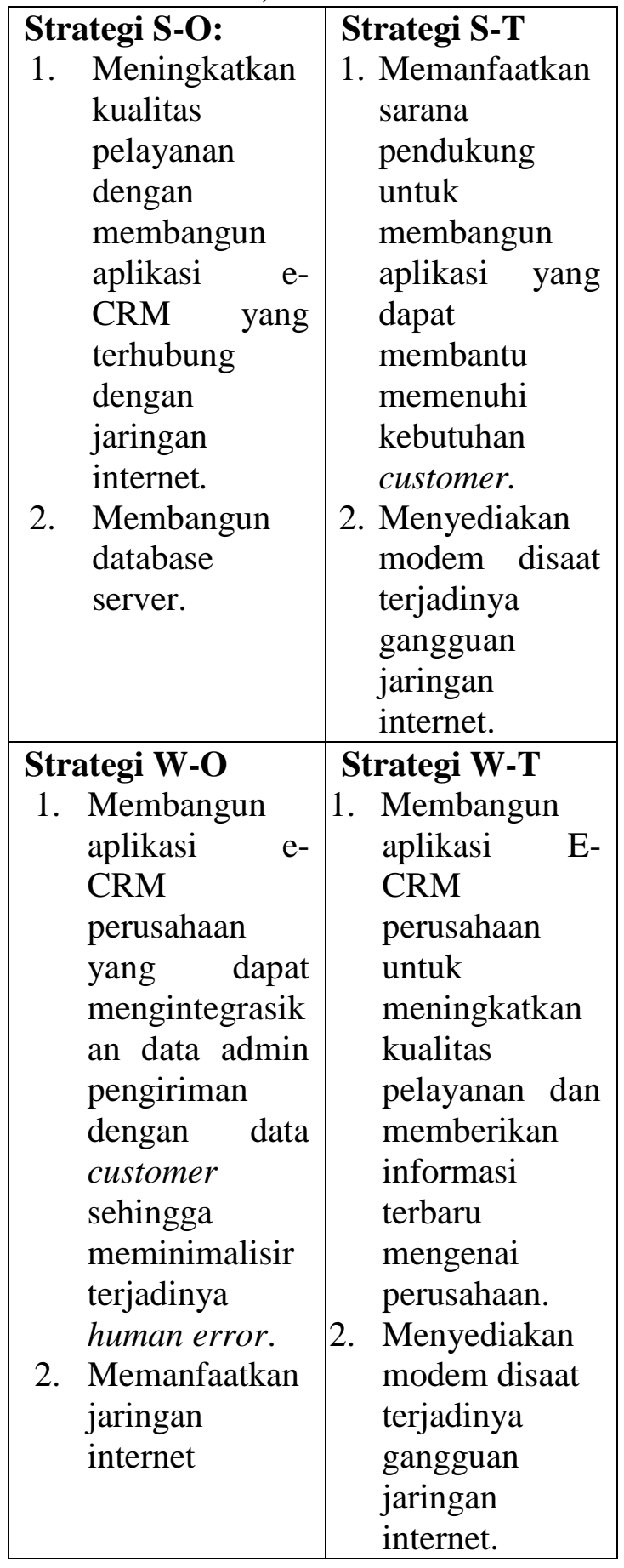

Usecase diagram

Use case diagram digunakan untuk memperlihatkan himpunan usecase dan aktor atau pelaku yang saling berinteraksi di dalam sistem [5]. Use case dipetakan untuk setiap business process, untuk mendefinisikan dengan tepat fungsional yang harus disediakan oleh sistem [1]. Berikut di bawah ini use case diagram rancangan electronic customer relationship management untuk panel pelanggan :

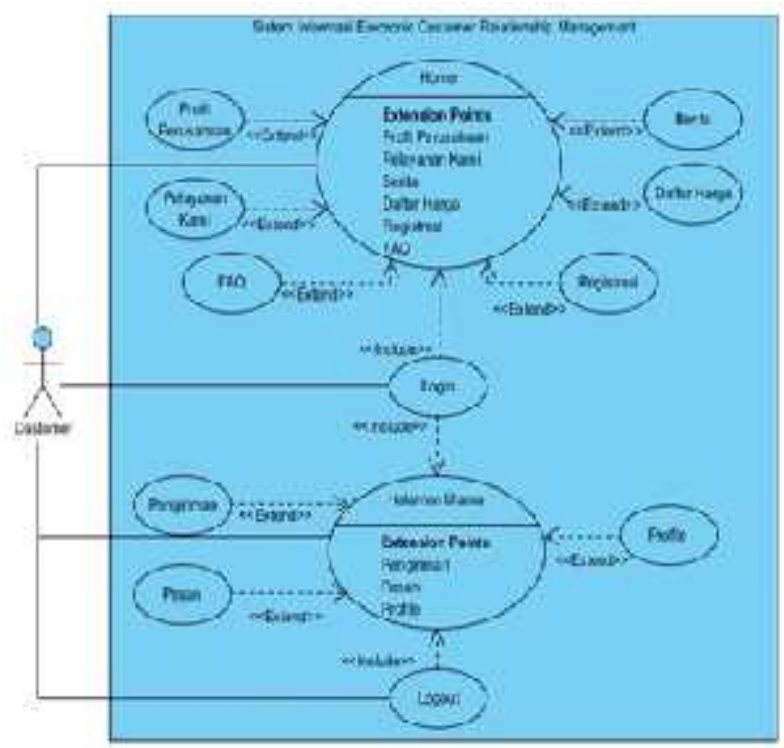

Gambar 3. Usecase diagram e-CRM

Pada gambar 3 di atas customer atau pelanggan dapat masuk ke dalam sistem dengan membuka alamat website. Di dalam sistem, melalui halaman home pelanggan dapat melihat profil perusahaan, berbagai jenis pelayanan yang ada di menu pelayanan kami, FAQ, berita, daftar harga dan registrasiuntuk dapat melakukan login dan masuk ke dalam halaman utama pelanggan. Di halaman utama, pelanggan dapat melakukan order melalui menu pesan, melihat pengiriman dan profil.

\section{Activity Diagram}

Setelah merancang diagram use case, dibuatlah diagram Activity dengan tujuan 
untuk memperlihatkan aliran dari suatu aktifitas ke aktifitas lainnya di dalam sistem. Diagram activity ini penting dibuat dalam pemodelan fungsi dalam pengembangan sistem dan memberi tekanan pada aliran kendali antar objek. Gambaran activity diagram rancangan aplikasi e-CRM dapat dilihat pada gambar 4 di bawah ini.

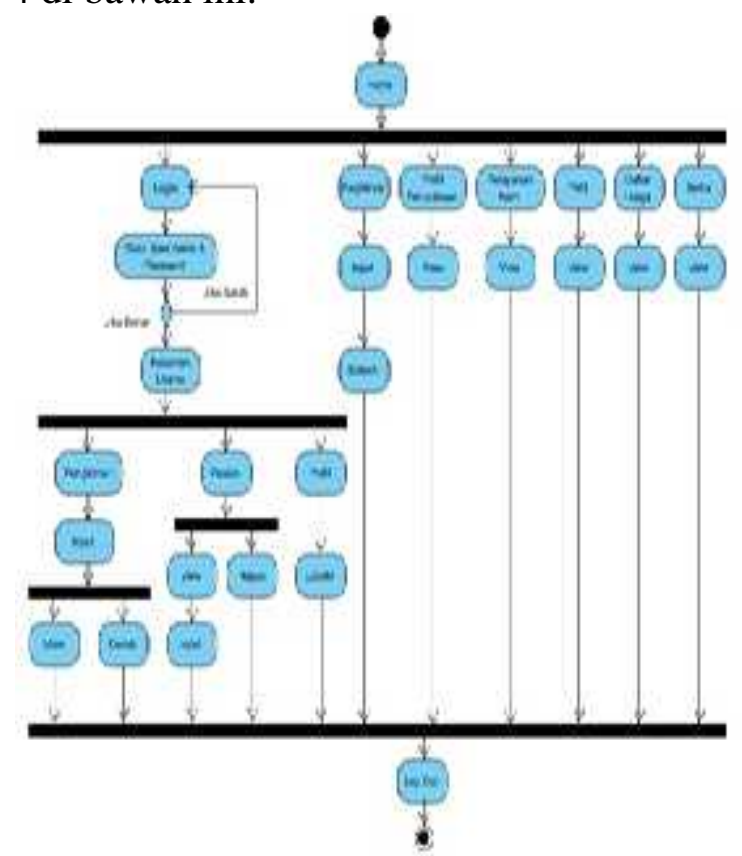

Gambar 4. Activity Diagram e-CRM

Gambar 4 di atas menjelaskan pelanggan dapat melihat profil perusahaan, pelayanan kami, FAQ, berita dan melakukan registrasi. Pelanggan yang sudah terdaftar dapat melakukan order melalui login dengan mengisi username dan password, jika keduanya salah maka login dinyatakan gagal dan harus mengulang isian username dan password kembali, dan jika username dan password benar maka pelanggan dapat masuk ke dalam halaman utama yang di dalamnya terdapat pilihan aktivitas pesan, pengiriman dan melihat profile.

\section{Class Diagram}

Class diagram digunakan untuk menggambarkan keadaan (atribut/property) suatu sistem, sekaligus menawarkan pelayanan untuk memanipulasi keadaan tersebut (metode/fungsi) [4]. Perancangan aplikasi e-CRM ini dibuat melalui penggambaran yang lengkap di setiap objeknya dengan memiliki nama kelas, atribut dan operation atau metode. Berikut adalah class diagram untuk rancangan aplikasi e-CRM :

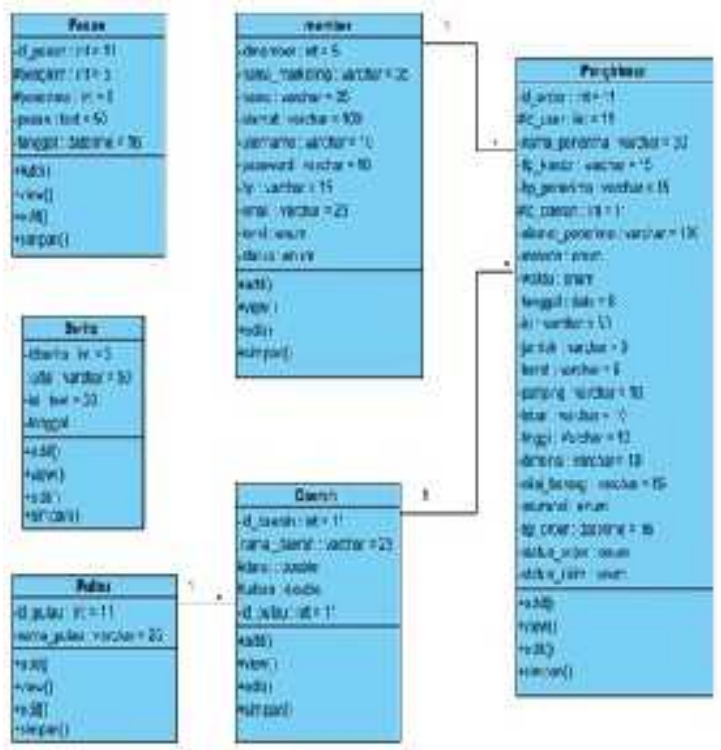

Gambar 5. Class Diagram

Terdapat 6 kelas yang dirancang dalam pembangunan aplikasi e-CRM, diantaranya terdapat tabel pesan, berita, member, pengiriman, pulau, dan daerah yang masing-masing tabel memiliki attribute sebagai propertinya. Kemudian dari 6 kelas tersebut dibangun database dengan menggunakan software MySQL sebagai media untuk menyimpan data.

\section{Tampilan Interface}

Berikut adalah hasil rancangan aplikasi eCRM : 
a. Tampilan Home

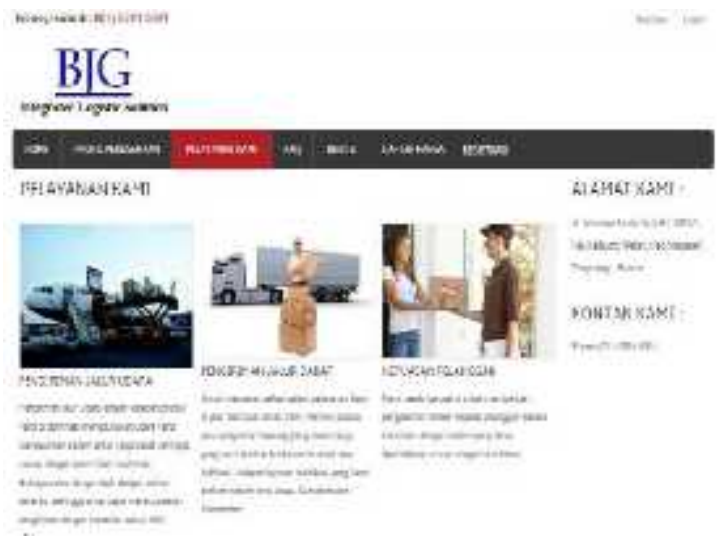

\section{Gambar 6. Tampilan home}

Pada gambar 6 di atas merupakan tampilan home dimana pelanggan dapat masuk ke dalam website dengan membuka alamat website, pelanggan dapat melihat profil perusahaan, jenis-jenis pelayanan yang tersedia dari menu pelayanan kami, FAQ, berita yang berisi informasi promo dari perusahaan, ucapan terima kasih, ucapan selamat ulang tahun dan informasi lainnya. Pelanggan juga dapat melihat daftar harga, dan melakukan registrasi untuk dapat order pengiriman barang.

\section{b. Tampilan Registrasi}

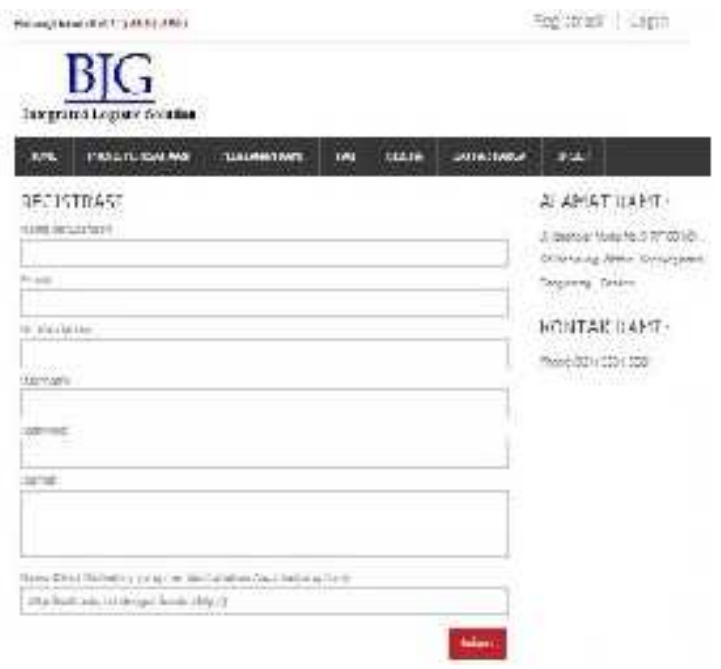

Gambar 7. Tampilan Registrasi
Gambar 7 di atas adalah tampilan registrasi untuk pelanggan. Pelanggan harus mengisi nama perusahaan, alamat email, nomor telepon atau handphone, alamat, membuat username dan password, serta mengisi nama divisi marketing yang memberitahukan anda tentang kami dengan keterangan jika tidak ada diisi dengan tanda strip (-). Seluruh isian harus terisi atau tidak boleh ada yang kosong.

c. Tampilan Buat Login

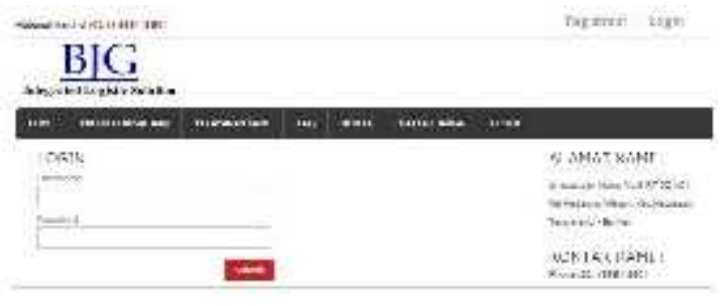

Gambar 8. Tampilan Buat Penugasan

Setelah melakukan registrasi, pelanggan dapat melakukan order pengiriman barang di halaman utama pelanggan melalui halaman login, di halaman login ini pelanggan harus memasukkan isian username dan password dengan benar, jika salah satu isian username atau password salah, sistem akan memberitahu ada kesalahan pengisian dan pelanggan harus mengulangi isian username dan password, dan jika benar maka pelanggan dapat melakukan order yang akan dicek oleh admin pengiriman melalui tampilan dibawah ini.

d. Tampilan Order Pengiriman Masuk oleh admin pengiriman. 


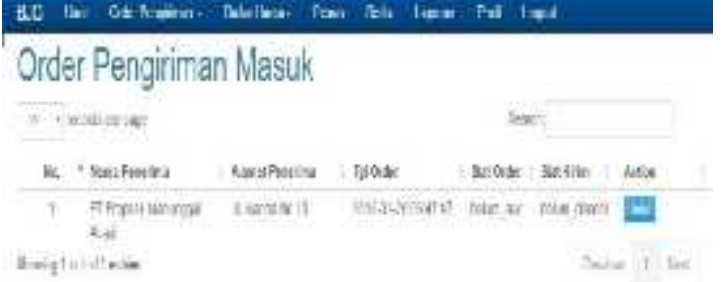

Gambar 9. Tampilan Order Pengiriman Masuk.

Setelah pelanggan melakukan order pengiriman barang, admin pengiriman barang akan mengecek setiap order yang masuk melalui tampilan gambar 9 di atas. Pada tampilan tersebut admin pengiriman barang dapat melihat nama penerima, alamat penerima, tanggal order, status order yang terdiri dari belum acc dan sudah cc, status kirim yang terdiri dari belum diambil, sudah diambil, sedang dikirim dan sudah sampai serta ada action button detail jika admin pengiriman ingin melihat data order pengiriman barang secara lebih rinci yang dapat dilihat pada gambar di bawah ini.

a. Tampilan Detail Pengiriman.

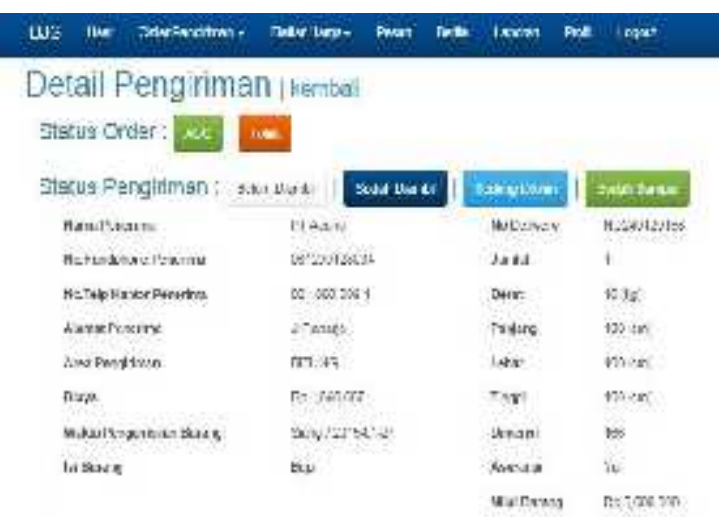

Gambar 10. Tampilan Detail Pengiriman
Pada tampilan detail pengiriman, admin pengiriman melakukan eksekusi status order yaitu di acc atau ditolak, selanjutnya admin peniriman juga melakukan eksekusi atau perubahan status berdasarkan informasi dari divisi pengiriman apakah barang sudah diambil, sedang dikirim hingga sudah sampai ke tangan penerima. Pada halam ini juga tertera informasi secara rinci data penerima dan data barang yang dikirim. Berdasarkan informasi ini, pelanggan dapat mengecek status pengiriman barang melalui halaman utama pelanggan dengan mudah, cepat serta dapat dilakukan dimana saja dan kapan saja.

\section{PENGUJIAN SISTEM}

Setelah rancangan aplikasi selesai, tahap berikutnya yang perlu dilakukan adalah pengujian sistem untuk memastikan seluruh tampilan dan fungsi-fungsi sistem telah sesuai dengan kebutuhan. Pada penelitian ini penulis menggunakan pengujian sistem menggunakan black box testing yang memiliki metode perancangan data uji didasarkan pada spesifikasi perangkat lunak. Data uji dibangkitkan, dieksekusi pada perangkat lunak kemudian output dari perangkat lunak diuji kesesuaiannya terhadap harapan pengguna [2]. Hasil pengujian black box sistem dapat dilihat pada tabel 3 di bawah ini. 
Tabel 3. Hasil Pengujian Sistem Dengan Black Box

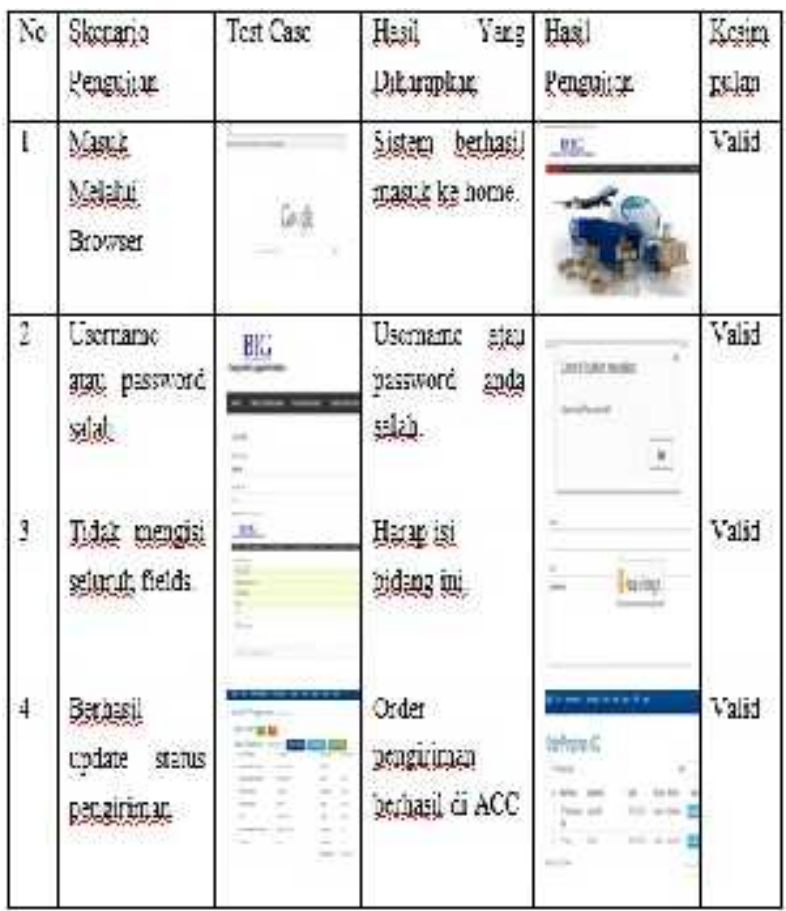

\section{KESIMPULAN}

Hasil pengujian black box testing terhadap rancangan aplikasi e-CRM menyatakan bahwa aplikasi ini dapat digunakan dalam mengelola hubungan baik dengan pelanggan dengan memberikan informasi seputar order pengiriman barang, status pengiriman barang hingga menyajikan informasi lainnya yang berguna bagi pelanggan dalam rangka menjaga loyalitas mereka kepada perusahaan. Selain itu aplikasi e-CRM ini juga mampu memberikan tampilan yang menarik dan penggunaan yang mudah.

\section{DAFTAR PUSTAKA}

1) Amrullah, Afif, 2011, "LangkahLangkah Penggunaan UML (Unified Modeling Language)". Bandung.

2) Budiman, Agustiar, 2012, "Pengujian Perangkat Lunak dengan Metode Black Box Pada Proses Pra Registrasi User Via Website", Makalah, halaman: 4.

3) Henderi, 2008, "Unified Modeling Language (UML): Konsep dan Implementasinya Pada Pemodelan Sistem Berorientasi Objek dan Visual".

4) Murad, 2010, "MetodeStruktur UML", Bandung: Informatika.

5) Nugroho, Adi, 2010, “Analisis Perancangan Sistem Informasi dengan Metodologi Berorientasi Object”, Bandung: Informatika

6) Rangkuti, Fredy, 2011, Balanced Scorecard: Teknik Menyusun Strategi Korporat yang Efektif plus Cara Mengelola Kinerja dan Resiko, Jakarta : PT Gramedia Pustaka Utama

7) Turbban, Efraim, 2004, Electronic Commerce a Managerial Perspective, Prentice Hall, New Jersey

8) Suyono, 2005, Shipping: Pengangkutan Intermodal Eksport Import Melalui Laut, edisi ke-3, Jakarta : PPM 